\title{
Error analysis applied to indirect methods for precipitation acidity
}

\author{
By HOWARD M. LILJESTRAND and JAMES J. MORGAN, California Institute of Technology, \\ Environmental Engineering Science, Pasadena, California 91125, U.S.A.
}

(Manuscript received February 6; in final form May 10, 1979)

\begin{abstract}
The historical increase in the acidity of precipitation in northern Europe has been monitored by direct measurements of $\mathrm{pH}$ and titrations of acidity. Indirect methods such as conductivity and charge balances as well as chemical source models have been used to confirm the measured acidities. In the absence of historical records of direct measurements of acidity in precipitation in the United States, indirect methods have been applied to available data on the composition of rainwater to quantify the acidity. Unfortunately, the indirect methods are sensitive to small errors in certain $\mathrm{pH}$ regions. The effects of random errors in major ion concentrations as well as the systematic errors due to the exclusion of trace metal and organic ions are shown to be largest around $\mathrm{pH} 5.6$ in the charge balance and chemical source strength calculations and largest around $\mathrm{pH} 6.1$ for the conductivity balance method. Estimates of the uncertainty in historical mean values of precipitation ion concentrations are used to calculate upper and lower bounds on the acidity of rainwater in the United States before 1970. The trend of increasing acidity of precipitation in the northeastern United States is still evident after applying error analysis.
\end{abstract}

\section{Introduction}

The historical increase in the acidity of precipitation in northern Europe has been followed in several ways. The first indications came in lakes with small drainage areas of slowly weathering soil which showed ecological shifts, decreases in fish populations and mortality of acid sensitive fauna. Transparency of the water increased over time as plankton decreased in concentration and humic substances precipitated (Dickson, 1975). After the establishment of a rainwater sampling network, direct measurements of $\mathrm{pH}$ and acidity/alkalinity by titration with base have recorded the spread and intensification of precipitation acidity in Scandinavia (Odén, 1968).

An increase in rainwater acidity over time for the northeastern United States has been determined by Cogbill and Likens (1974) although the historical record of acidity measurements is sporadic. The more complete records of major cation and anion concentrations have been used with chemical relationships to calculate $\mathrm{pH}$ values. Since a variety of direct and indirect methods to quantify the acidity of precipitation have been used, discrepancies between the values determined by direct measurements and indirect methods have been noticed (Granat, 1972). To clarify the differences and encourage meaningful determinations of acidity in the future, the applicability and limitations of each method should be examined. In particular, the sensitivity of indirect methods to random and systematic errors should be determined to provide confidence limits on values derived from historical data so that real changes over time can be detected.

\section{Variation in precipitation concen- trations}

Much of the historical ion concentration data is given in the form of the precipitation weighted mean. In analogy to the mass concentration pre- 
cipitation weighted mean defined by Lodge et al. (1968), the molar precipitation weighted mean is given by

$$
\overline{[x]}=\frac{\sum_{i=1}^{i=n} P_{i}[x]_{i}}{\sum_{i=1}^{i=n} P_{i}}
$$

where $n$ is the number of samples, $[x]$ is the mean molar concentration, $[x]_{i}$ is the molar concentration of the $i$ th sample, and $P_{i}$ is the precipitation amount $(\mathrm{mm})$ during the collection of the $i$ th sample. Thus, the mean value is the mole flux of a chemical species divided by the volume flux of water and represents the value that would be measured if all samples were mixed together and analyzed as one. This value has meaning only for conservative species or quantities.

To provide confidence limits to the weighted mean values, Miller (1977) has proposed a precipitation weighted standard deviation for the mean $\left(s_{\text {p.w.m. }}\right)$ as given by

$$
\left(s_{\mathrm{p} . \mathrm{w} . \mathrm{m} .}\right)^{2}=\frac{1}{n}\left(\frac{1}{\sum_{i=1}^{i=n} P_{l}}\right) \sum_{i=1}^{i=n} P_{i}\left([x]_{i}-\overline{[x]}\right)^{2}
$$

This standard deviation includes random analytical errors as well as natural variation in the rainwater composition of the samples collected. It does not include the variation between samples at the same site or systematic errors due to improper sample collection and preservation as described by Galloway and Likens (1978) nor does it include the spatial variability as described by Granat (1977).

While there are other ways to show the uncertainty in the mean, the standard deviation given in eq. (2) is useful for several reasons. For the case of all samples having the same precipitation amount, $s_{\text {p.w.m. }}$ shows a $1 / n$ dependence, as would be expected, for $n$ a large number. The standard deviation reflects the random sampling of a population of storms for a particular site. So long as the precipitation sampling is not biased, the standard deviation gives the variation even if all the samples are not analyzed due to contamination or insufficient volume. If the periods of sampling and analysis of the major ions are not identical, the precipitation weighted standard deviation reflects the uncertainty of using the mean values for dissimilar

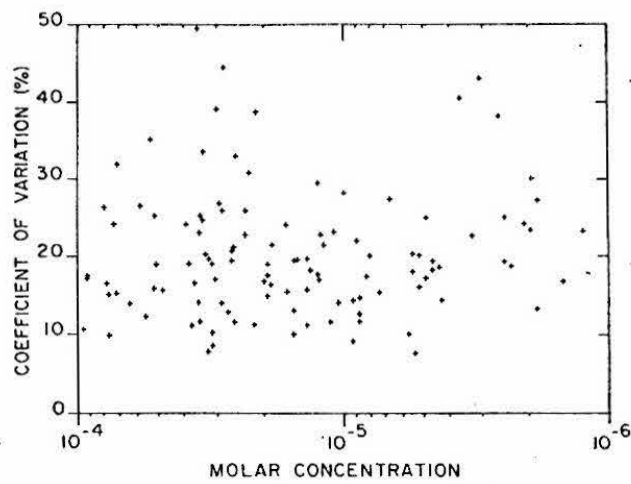

Fig. 1. Coefficient of variation of the precipitation weighted mean vs mean molar concentration for major cation and anion species.

time intervals. If the weather patterns are abnormally wet or dry during part of the sampling period, then the standard deviation will be higher to reflect the uncertainty of the mean values for normal precipitation during that period. Trends based on discontinuous sampling periods can be better estimated with confidence limits which include the natural variation in rainwater composition.

The coefficient of variation $(V)$ gives the percent error and is defined by

$V=\frac{s_{\text {p.w.m. }}}{[\overline{x]}}$

Fig. 1 shows typical coefficients of variation for major cation and anion species in rainwater in the United States. These values were derived from the data of Miller (1977), The MAP3S Precipitation Network (1977), WMO, EPA and NOAA (1975, 1976, 1977), Liljestrand and Morgan (1978), and Kennedy et al. (1976) which represent samples collected by month, by storm and by increments within a storm. The coefficient of variation is seldom less than $10 \%$ or more than $30 \%$. Ten per cent and $30 \%$ will be used as lower and upper bounds, respectively, on the variation for historical data that provides only mean values.

\section{Charge balance method}

A charge balance exists when all the major ion concentrations are known. However, all the major ion concentrations are not necessarily known if 
there is a charge balance of the measured ion concentrations. If all the major cations and anions with the exceptions of the hydrogen, hydroxide, bicarbonate, and carbonate ions can be assumed to be known, then the charge balance can be used with equilibrium relationships to solve for the $\mathrm{pH}$. The charge balance is given by

$$
\begin{aligned}
& {\left[\mathrm{H}^{+}\right]+\left[\mathrm{NH}_{4}^{+}\right]+\left[\mathrm{Na}^{+}\right]+\left[\mathrm{K}^{+}\right]+2\left[\mathrm{Ca}^{2+}\right]} \\
& +2\left[\mathrm{Mg}^{2+}\right]+\sum_{i} z_{l}\left[\mathrm{Me}_{i}^{z+}\right]=\left[\mathrm{OH}^{-}\right]+\left[\mathrm{HCO}_{3}^{-}\right] \\
& +2\left[\mathrm{CO}_{3}^{2--}\right]+\left[\mathrm{Cl}^{-}\right]+\left[\mathrm{NO}_{3}^{-}\right]+2\left[\mathrm{SO}_{4}^{2-}\right] \\
& +\sum_{J}\left|z_{j}\right|\left[A_{j}^{z j-}\right]
\end{aligned}
$$

where $\left[\mathrm{Me}_{i}^{z^{\dagger}}\right]$ represents the molar concentration of the $i$ th trace cationic species of charge $+z_{i}$ and $\left[A_{j}^{z j}-\right]$ represents the molar concentration of the $j$ th trace anionic species of charge $-z_{j}$. If the sample is in equilibrium with a known partial pressure of carbon dioxide, then the following equilibrium relationships can be used.

$K_{H}=\frac{\left[\mathrm{H}_{2} \mathrm{CO}_{3}^{*}\right]}{P_{\mathrm{CO}_{2}}}$

$$
K_{1}=\frac{\left[\mathrm{H}^{+}\right]\left[\mathrm{HCO}_{3}^{-}\right]}{\left[\mathrm{H}_{2} \mathrm{CO}_{3}^{*}\right]}
$$

$$
K_{2}=\frac{\left[\mathrm{H}^{+}\right]\left[\mathrm{CC}_{3}^{-}\right]}{\left[\mathrm{HCO}_{3}^{-}\right]}
$$

$$
K_{W}=\left[\mathrm{H}^{+}\right]\left[\mathrm{OH}^{-}\right]
$$

$\left[\mathrm{H}_{2} \mathrm{CO}_{3}^{*}\right]$ is defined as the sum of $\left[\mathrm{CO}_{2 \text { (aq) }}\right]$ and $\left[\mathrm{H}_{2} \mathrm{CO}_{3(\mathrm{aq})}\right]$. Stumm and Morgan (1970) showed how acidity, alkalinity, $\mathrm{pH}$, and species concentrations are related for aqueous systems in equilibrium with an atmospheric partial pressure of carbon dioxide of 315 p.p.m. Acidity and alkalinity are defined as the equivalents per liter of base and acid, respectively, needed to titrate a sample to the $\mathrm{pH}$ of pure water in equilibrium with a fixed partial pressure of carbon dioxide. For $P_{\mathrm{CO}_{2}}$ equal to 315 p.p.m., the endpoint $\mathrm{pH}$ is 5.65. Combining equations and separating the unknowns leads to eq. (9) which can be solved for the hydrogen ion concentration, if the difference in the trace cation and anion equivalent concentrations is assumed insignificant $\left(\sum_{i} z_{i}\left[\mathrm{Me}_{i}^{z_{i}^{i}}\right]-\sum_{j} \mid z_{j}\left[A_{j}^{z-}\right] \cong 0\right)$.

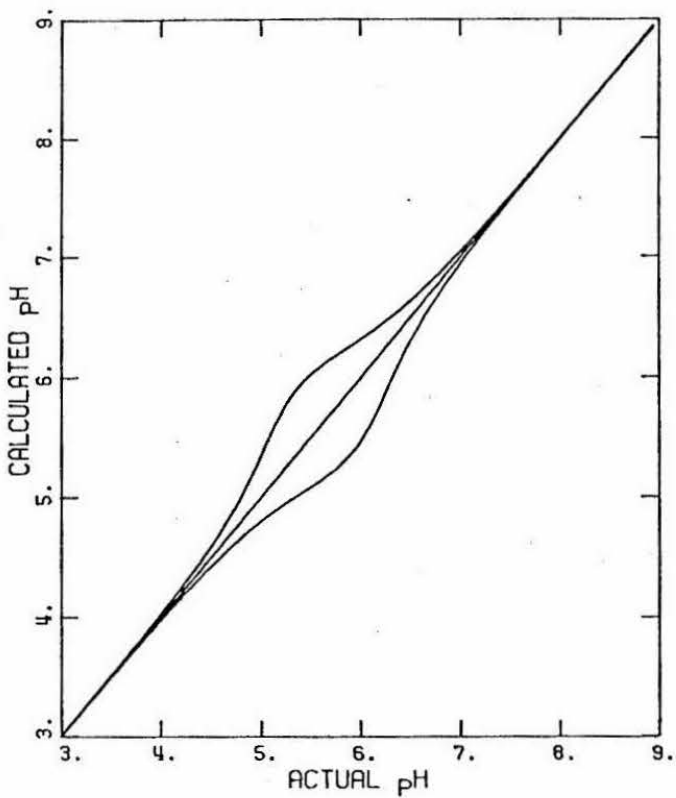

Fig. 2. The $68.3 \%$ confidence level $( \pm 1$ standard deviation of $6 \mu$ equivalents/liter) in calculated $\mathrm{pH}$ vs actual pH. $6 \mu$ equivalents/liter is a lower bound for $\sqrt{\sigma_{\mathrm{NSO}_{4}}^{2}+\sigma_{\mathrm{NCl}}^{2}+\sigma_{\mathrm{NNO},}^{2}+\sigma_{\mathrm{NNa}}^{2}+\sigma_{\mathrm{NK}}^{2}+\sigma_{\mathrm{NMg}}^{2}+\sigma_{\mathrm{NCa}}^{2}}$ for precipitation in the United States.

$$
\begin{aligned}
& {\left[\mathrm{H}^{+}\right]-\frac{K_{W}}{\left[\mathrm{H}^{+}\right]}-P_{\mathrm{CO}_{2}} \frac{K_{H} K_{1}}{\left[\mathrm{H}^{+}\right]}-2 P_{\mathrm{CO}_{2}} \frac{K_{H} K_{1} K_{2}}{\left[\mathrm{H}^{+}\right]^{2}}} \\
& \left.+\sum_{i} z_{i}\left[\mathrm{Me}_{i}^{z+}\right]-\sum_{j}\left|z_{j}\right|\left[A^{z}\right]-\right]=\left[\mathrm{CL}^{-}\right]+\left[\mathrm{NO}_{3}^{-}\right] \\
& +2\left[\mathrm{SO}_{4}^{2-}\right]-\left[\mathrm{NH}_{4}^{+}\right]-\left[\mathrm{Na}^{+}\right]-\left[\mathrm{K}^{+}\right]-2\left[\mathrm{Ca}^{2+}\right] \\
& -2\left[\mathrm{Mg}^{2+}\right]
\end{aligned}
$$

The error of the hydrogen ion concentration calculated by eq. (9) is determined by the validity of the assumptions and the uncertainty in the known major ion concentrations. If the $i$ th major ion with mean concentration $\left[X_{i}\right]$ and charge $z_{i}$ has a coefficient of variation $V_{i}$, then the uncertainty for the right-hand side of eq. (9) is given by

$s_{\mathrm{R} . \mathrm{H} . \mathrm{s} .}^{2}=\sum_{i=1}^{i=n}\left(V_{i}\left[X_{i}^{z_{i}}\right] z_{i}\right)^{2}$

Assuming the data of Lodge et al. (1968), Junge (1958) and Junge and Werby (1958) have coefficients of variation of only $10 \%$, then $s_{\text {R.H.s. }}$ is greater than or equal to 6 microequivalents/liter for rainwater in most of the United States. Fig. 2

Tellus 31 (1979), 5 
shows the $68.3 \%$ confidence limit $\left( \pm 1 \cdot s_{\text {R.H.S. }}\right)$ for the calculated $\mathrm{pH}$ vs the actual $\mathrm{pH}$ with 6 microequivalents/liter uncertainty in the right-hand side of eq. (9). At $\mathrm{pH} 5.65$, the calculated $\mathrm{pH}$ varies from 5.17 to 6.13 due to random fluctuations in the major ion concentrations. The maximum uncertainty due to small differences in relatively large numbers occurs at $\mathrm{pH} 5.65$ where the hydrogen ion concentration equals the bicarbonate concentrations. When the alkalinity and acidity are close to zero, random variation in the major ion concentrations becomes significant.

An implicit assumption in eq. (10) for the calculation of $s_{\text {R.H.S. }}$ is that each major ion varies independently of the others. Since many ions come from the same sources, there is some covariance between the major ions (Lodge et al., 1968, Miller, 1977; Larson and Hettick, 1956). The covariance between the data used is not well known. Since data is often pieced together from different sampling periods as in the NCAR study (Lodge et al., 1968), and different locations as in estimating $\mathrm{Ca} / \mathrm{Mg}$ ratios and $\mathrm{NH}_{4} / \mathrm{NO}_{3}$ ratios (Cogbill and Likens, 1974) and different samples within the same sampling period as in the case of insufficient sample volume for a complete analysis of all the chemical species being studied, the covariance may be low. In addition, if the chemical species concentrations are assumed to be well correlated as in the chemical tracers or source strength model discussed below and the variations of the source strengths are considered, $s_{\text {R.н.s. }}$ still has a minimum of about 6 microequivalents/liter.

In addition to the uncertainty due to random variation in the major ion concentrations, there are uncertainties due to systematic errors in the model. The assumption that the trace anion and cation concentrations are insignificant may not be true around $\mathrm{pH}$ 5.65. Studies of rainwater chemistry that included trace metal ion concentrations show that they may contribute more than 1 microequivalent/l to the charge balance (Lazrus et al, 1971; Liljestrand and Morgan, 1978; Galloway et al., 1976). Concentrations of organic cations are not well known but Galloway et al. (1976) found organic anion concentrations on the order of 1 microequivalent/liter. In acidic solution, the organic acids will tend to be protonated and uncharged while in basic rainwater the trivalent metal ions will hydrolyze, precipitate, and con-

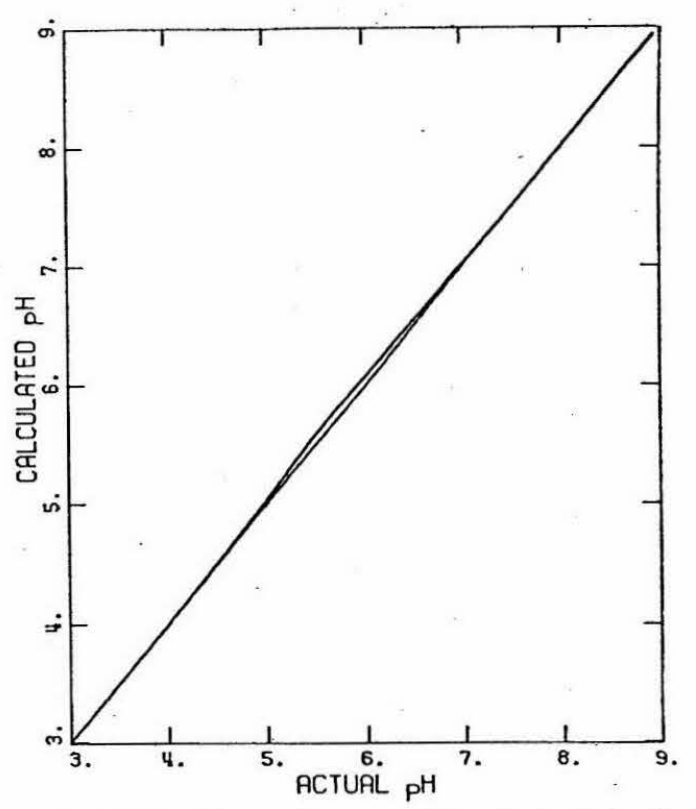

Fig. 3. Effect of trace ions on $\mathrm{pH}$ calculated by the charge balance or the source strength model vs actual $\mathrm{pH}$. Trace ion concentrations are assumed to be $5 \mu \mathrm{M}$ organic acid of $\mathrm{p} K_{\mathrm{a}}=4.3,1 \mu \mathrm{M}$ iron(III), $1 \mu \mathrm{M}$ aluminium(III), and $1 \mu \mathrm{M}$ divalent metal cation.

tribute less to the charge balance. Fig. 3 shows the error in the calculated $\mathrm{pH}$ by excluding $5 \mu \mathrm{M}$ of organic acid with $\mathrm{p} K_{\mathrm{a}}=4.3,1 \mu \mathrm{M}$ iron(III), $1 \mu \mathrm{M}$ aluminium and $1 \mu \mathrm{M}$ divalent trace metal cation from the charge balance equation. In this case, the equivalent concentrations of trace cations and anions balance at $\mathrm{pH} \mathrm{5.05}$. The error is only 0.08 $\mathrm{pH}$ units at $\mathrm{pH} 5.65$.

Sulfite species have been considered a trace species in eq. (4). If the time between sample collection and analysis is long, the sulfite species may be oxidized to and analyzed as sulfate. For $\mathrm{pH}$ greater than 7.2, there is no additional error. For $\mathrm{pH}$ values between 1.7 and 7.2 , the error in assuming bisulfite ions to be part of the measured total sulfate is $-\left[\mathrm{HSO}_{3}^{-}\right]$in the right-hand side of eq. (9). The magnitude of this error may be less than 1 microequivalent/ 1 as indicated by measured total sulfite concentrations or may be as much as 10 microequivalents/l in some locations based on equilibrium solubility calculations (MAP3S, 1977).

Another assumption in the charge balance model 


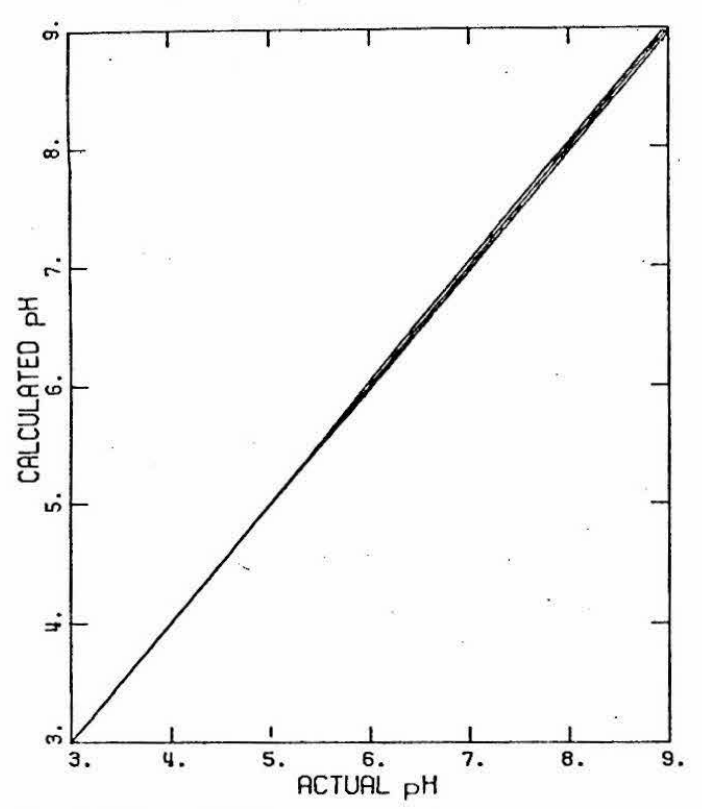

Fig. 4. Effect of $10 \%$ uncertainty in the partial pressure of carbon dioxide on the calculated $\mathrm{pH}$ vs the actual $\mathrm{pH}$.

is equilibrium with the atmospheric partial pressure of carbon dioxide. While Miller (1952) considered rainfall in areas of metal carbonate soil to be close to gas-liquid-solid equilibrium, there is still some uncertainty about the partial pressure of carbon dioxide with which the precipitation sample is in equilibrium. Ekdahl and Keeling (1973) reported seasonal variations of 6 p.p.m. $\mathrm{CO}_{2}$ and an annual increase of 0.8 p.p.m. per year at the Mauna Lao observatory in Hawaii. Allowing for local variations in the partial pressure of carbon dioxide due to anthropogenic emissions and high photosynthetic activity, the uncertainty in $P_{\mathrm{CO}_{2}}$ could be less than 10\% (Bischof and Bolin, 1966). Fig. 4 shows this uncertainty results in a difference between calculated and actual $\mathrm{pH}$ of $0.04 \mathrm{pH}$ units for basic samples. If samples are in equilibrium with a higher $P_{\mathrm{CO}_{2}}$ as in the laboratory environment, the uncertainty is higher. If $P_{\mathrm{CO}_{2} \text { (actual) }}$ is twice $P_{\mathrm{CO}_{2} \text { (assumed) }}$ then actual $\mathrm{pH}$ is less than calculated $\mathrm{pH}$ by $0.3 \mathrm{pH}$ units for samples with alkalinity greater than $10 \sqrt{K_{1} K_{H} P_{\mathrm{CO}_{2} \text { (assumed) }}}$ and by less than $0.005 \mathrm{pH}$ units for samples with acidity greater than $10 \sqrt{K_{1} K_{H} P_{\mathrm{CO}_{2} \text { (assumed) }}}$.

\section{Source strength methods}

Granat (1972) developed a source strength model to calculate $\mathrm{pH}$ values in European rainwater from major cation and anion concentrations. The model uses sodium as a tracer to calculate the sea salt contribution or source strength to the chemical composition of the rainwater. The sea salt is assumed to be neutral and to contribute no acidity or alkalinity to the precipitation. The non-sea salt components are assumed to be due to basic gas (ammonia), acidic gas products (sulfuric and nitric acids) and alkaline soil dust (potassium, calcium and magnesium carbonate). The net acidity or alkalinity of the rainwater is assumed to be the difference between acidity of the acid sources $\left(\mathrm{H}_{2} \mathrm{SO}_{4}, \mathrm{HNO}_{3}\right)$ and alkalinity from the basic sources $\left(\mathrm{NH}_{3}\right.$, metal carbonates). Given the relationships between alkalinity, acidity, and $\mathrm{pH}$ in aqueous systems open to atmospheric carbon dioxide, the $\mathrm{pH}$ is fixed (Stumm and Morgan, 1970). For $\mathrm{pH}$ values less than 8 , the Granat model reduces to the following equation:

$$
\begin{aligned}
& {\left[\mathrm{H}^{+}\right]-\frac{P_{\mathrm{CO}_{2}} K_{H} K_{1}}{\left[\mathrm{H}^{+}\right]} \cong\left[\mathrm{NO}_{3}^{-}\right]+2\left[\mathrm{SO}_{4}^{2-}\right]} \\
& +0.1875\left[\mathrm{Na}^{+}\right]-\left[\mathrm{K}^{+}\right]-2\left[\mathrm{Ca}^{2+}\right]-2\left[\mathrm{Mg}^{2+}\right] \\
& -\left[\mathrm{NH}_{4}^{+}\right]
\end{aligned}
$$

By excluding the chloride concentration and reducing the sodium concentration's relative weight, Granat's source strength model is subject to smaller errors due to random uncertainty in the major ion concentrations than the previous methods. For non-coastal sites in the U.S. before 1970 , Granat's method is subject to random errors which are slightly less than the random errors in the charge balance method. The maximum uncertainty in calculated $\mathrm{pH}$ again comes at $\mathrm{pH} 5.65$, and Fig. 2 is applicable to a 6 microequivalents/l uncertainty in the right-hand side of eq. (11). If hydrogen chloride air pollutants are considered to be a source of acidity and the alkalinity of sea salt aerosol is included in Granat's model, the source strength model has the same eq. (9) as the charge balance model, and the magnitude of the random errors for both models would be exactly the same.

Source strength methods are subject to sytematic as well as random errors. The exclusion 
of trace ions and; therefore, sources of alkalinity/acidity has the same error as that for the charge balance method. Likewise, any incorrect assumption of partial pressure of carbon dioxide has the same effect on both methods, and Fig. 3 and 4 are equally applicable to the source strength model under the same assumptions.

\section{Conductivity balance method}

An approach analogous to the charge balance is the conductivity balance. The specific conductance $(\Lambda)$ in units $(\mathrm{ohm}-\mathrm{cm})^{-1}$ of a sample can be calculated from the ion concentrations $\left(\left[X_{i}\right]\right)$ if the ionic conductances $\left(\lambda_{i}\right)$ in units $(\mathrm{ohm}-\mathrm{cm}-\mathrm{N})^{-1}$ are known.

$\Lambda=\sum_{i} \lambda_{i}\left[X_{i}^{z_{i}}\right]\left|z_{i}\right|$

Alternatively, if the specific conductance is known, the hydrogen ion concentration can be determined by invoking the same equilibria used in the previous methods. The difference between the measured conductivity and that due to the known ion concentrations is assumed to be due to the conductivity from hydrogen, hydroxide, bicarbonate and carbonate ions.

$$
\begin{aligned}
\Lambda & =\sum_{j=1} \lambda_{j}\left[X_{j}\right] z_{j}=\lambda_{\mathrm{H}^{+}}\left[\mathrm{H}^{+}\right]+\lambda_{\mathrm{HCO}_{3} \frac{P_{\mathrm{CO}_{2}} K_{H} K_{1}}{}}^{\left[\mathrm{H}^{+}\right]} \\
& +\lambda_{\mathrm{OH}^{-}} \frac{K_{W}}{\left[\mathrm{H}^{+}\right]}+2 \lambda_{\mathrm{Co}^{-}} \frac{P_{\mathrm{CO}_{2}} K_{H} K_{1} K_{2}}{\left[\mathrm{H}^{+}\right]^{2}}
\end{aligned}
$$

This method has some distinct advantages and disadvantages. Since Lodge et al. (1968) measured total nitrogen rather than ammonium and nitrate separately, estimates of the ammonium-to-nitrate ratio must be made to use the data in the charge balance and source strength methods. A poor guess in this cation to anion or acid-to-base ratio will result in a large error. Since the ion conductances of ammonium and nitrate are very similar, a poor guess at the ammonia-to-nitrate ratio will give a small error when using total nitrogen data in the conductivity balance method.

Unfortunately, eq. (13) does not give a unique solution. The excess conductance calculated on the left-hand side can be attributed to hydrogen ion in an acid solution or bicarbonate and hydroxide ions in an alkaline solution. A charge balance or source strength model must be used in conjunction with the conductance balance method to find the solution of eq. (13) representing the $\mathrm{pH}$.

Since the specific conductance is not a conservative quantity, $\mathrm{pH}$ calcualtions must be made for each sample, rather than using mean concentrations to calculate a mean $\mathrm{pH}$. Thus, only samples for which there is both specific conductance data and all the major ion data can be analyzed with this method. The uncertainty in the known data will be that due to the analytical error without including the natural variation in rainwater composition. The specific conductance measurement provides another source of random error, and the problem of small differences in large numbers is more acute than with the previous models.

Fig. 5 shows the effects of random errors on the conductivity balance. The uncertainty of the lefthand side of eq. (13) is assumed to be \pm 0.4 $\mu \mathrm{mho} / \mathrm{cm}$, which should be a median value for the uncertainty for samples collected in areas with the lowest specific conductance in the United States, assuming analytical errors are $5 \%$. The region of maximum uncertainty is at $\mathrm{pH} 6.1$, where $\lambda_{\mathrm{H}^{+}}\left[\mathrm{H}^{+}\right]$ $\cong \lambda_{\mathrm{HCO}_{3}^{-}}\left[\mathrm{HCO}_{3}^{-}\right]+\lambda_{\mathrm{OH}^{-}}\left[\mathrm{OH}^{-}\right]$and small differences in large numbers are most pronounced. The limits of uncertainty are discontinuous due to the switch in the choice of solutions to eq. (13) as determined by the charge balance equation. In addition, there is no solution when the random errors cause the conductance due to the known ions to be greater than the measured conductance, or when the left-hand side of eq. (13) is less than the minimum possible for the right-hand side of eq. (13) as determined by equilibrium with atmospheric carbon dioxide.

Systematic errors are larger in the conductance balance than in the previous methods. While the ion conductances of large ions, such as organic ions, are relatively lower than those of the major ions, the uncertainty due to the exclusion of trace ions is larger than in the charge balance method. There is no cancellation of errors due to opposite signs as in the charge balance. Fig. 6 shows the error calculated $\mathrm{pH}$ by excluding the same concentrations of trace ions as used in Fig. 3. 


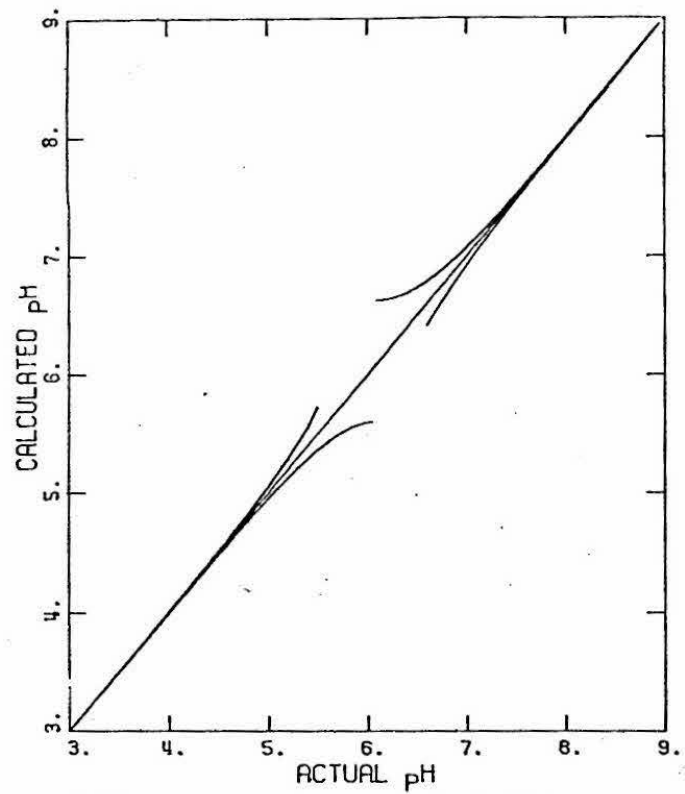

Fig. 5. The $68.3 \%$ confidence level $( \pm 1$ standard deviation of $0.4 \mu \mathrm{mho} / \mathrm{cm}$ ) in $\mathrm{pH}$ calculated by the conductivity balance vs actual $\mathrm{pH}$.

\section{Applications to historical data}

Fig. 2 shows that a given small amount of error has the largest effect if the actual $\mathrm{pH}$ is around 5.65 in the charge balance and source strength methods. Actually, random errors increase with increasing alkalinity and increasing acidity, and tend to be a minimum at $\mathrm{pH} 5.65$. Thus, the uncertainty in the alkaline and acid regions is typically higher than implied by Fig. 2 due to larger random errors in these regions.

\subsection{Measured vs calculated $p H$}

In using the historical major ion concentration data of Junge (1958), Junge and Werby (1958), Lodge et al. (1968), WMO, EPA and NOAA $(1975,1976,1977)$ and others to calculate mean $\mathrm{pH}$ values, the effects of random errors must be considered for each site. To test the importance of error analysis, the measured mean $\mathrm{pH}$ and calculated mean $\mathrm{pH}$ using the charge balance including error analysis are compared using the WMO,

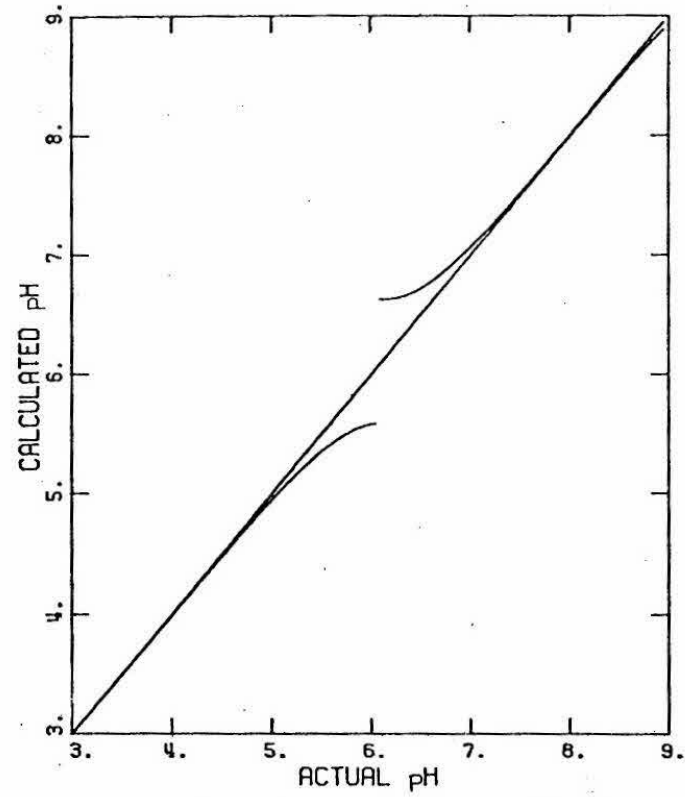

Fig. 6. Effect of trace ions on pH calculated by the conductivity balance vs actual $\mathrm{pH}$. Trace ion concentrations are assumed to be $5 \mu \mathrm{M}$ organic acid of $\mathrm{p} K_{\mathrm{a}}=4.3,1 \mu \mathrm{M}$ iron(III), $1 \mu \mathrm{M}$ aluminium(III), and $1 \mu \mathrm{M}$ divalent metal cation.

EPA and NOAA $(1975,1976,1977)$ data. Assuming no weak acids other than $\mathrm{NH}_{4}^{+}$are present, the acidity/alkalinity of each monthly sample is calculated from the measured $\mathrm{pH}$. These acidity/alkalinity values are averaged to give the precipitation weighted mean acidity/alkalinity and the corresponding precipitation weighted mean $\mathrm{pH}$. This mean $\mathrm{pH}$ is compared with the mean $\mathrm{pH}$ calculated from the known major cation and anion concentrations, other than $\mathrm{H}^{+}$, by the charge balance method (eq. (9)). The variation in measured mean $\mathrm{pH}$ and the mean $\mathrm{pH}$ calculated by the charge balance represents one and two standard deviations of random variation in the mean acidity/alkalinity and of variation in the major ion concentrations, respectively. Acidity/alkalinity values are averaged instead of $\left[\mathrm{H}^{+}\right]$, because acidity and alkalinity are conservative quantities assuming a fixed partial pressure of carbon dioxide. $\left[\mathrm{H}^{+}\right]$is not a conservative quantity, especially when samples of $\mathrm{pH}$ greater than 5.65 are averaged with samples of $\mathrm{pH}$ less than 5.65. Data for twoyear periods for sixteen sites in the United States

Tellus 31 (1979), 5 


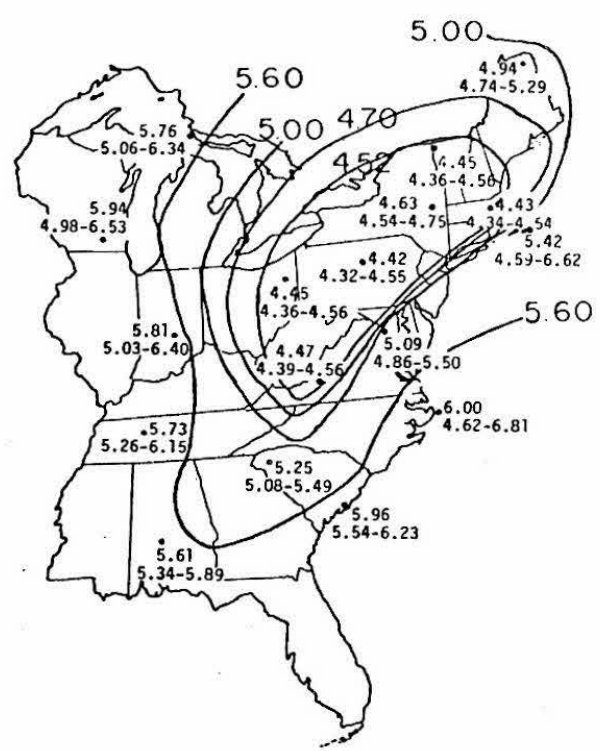

Fig. 7. Calculated mean $\mathrm{pH}$ values for the eastern United States during 1955-56. Contours and top values for each site calculated by Cogbill and Likens (1974). The range in mean pH for each site is the $68.3 \%$ confidence level calculated from the data of Junge (1958) and Junge and Werby (1958) assuming a $10 \%$ coefficient of variation in the known ion concentrations.

are averaged. Of the twenty-eight data sets, thirteen show agreement between the calculated and measured $\mathrm{pH}$ within one standard deviation, eight show agreement within two standard deviations, and five show agreement within slightly more than two standard deviations. The WMO, EPA and NOAA data confirm the necessity of including error analysis to bound the actual mean $\mathrm{pH}$ when using indirect methods.

Granat (1972) validated his source strength model by comparing measured and calculated $\mathrm{pH}$ values for individual rainwater samples showing acidity as well as alkalinity. The calculated $\mathrm{pH}$ agreed with the measured values within $\pm 0.15 \mathrm{pH}$ units. The individual samples would be subject to analytical errors but not be subject to variation in major ion concentrations that arise from the use of mean values. Likewise, Cogbill and Likens (1974) confirmed their modeling by comparing weighted mean measured and calculated $\mathrm{pH}$ values for five sites with $\mathrm{pH} \leq 4.2$. The agreement was quite good for these average values, and the agreement was purported to be within $0.1 \mathrm{pH}$ units for the individual samples.

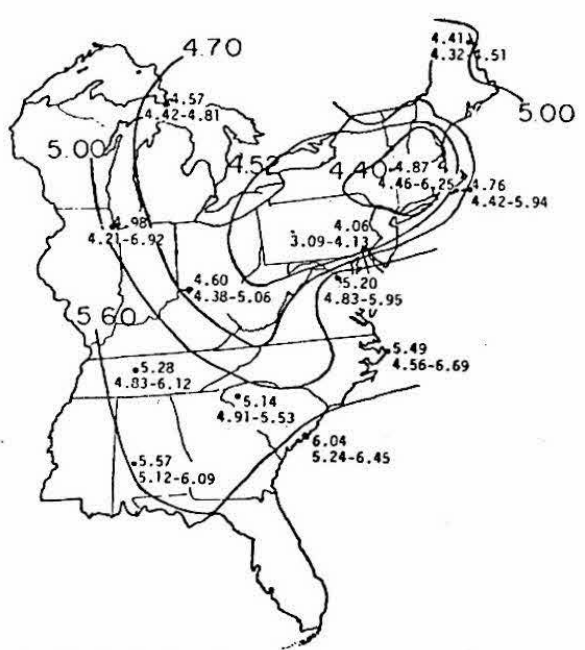

Fig. 8. Calculated mean pH values for the eastern United States during 1965-66. Contours and top values for each site calculated by Cogbill and Likens (1974). The range in mean $\mathrm{pH}$ for each site is the $68.3 \%$ confidence level calculated from the data of Lodge et al. (1968) assuming a $10 \%$ coefficient of variation in the known ion concentrations. Additional data points from direct measurements of $\mathrm{pH}$ in the Northeast, Virginia, and North Carolina have been omitted.

\subsection{Eastern United States}

Using the calculated mean $\mathrm{pH}$ values of Cogbill and Likens (1974) and assuming only a 10\% uncertainty in the ion concentration data of Junge (1958), Junge and Werby (1958) and Lodge et al. (1968), the $68.3 \%$ confidence limits $\left( \pm 1 s_{\text {R.H.s. }}\right.$ ) for the mean $\mathrm{pH}$ values can be calculated. Figs. 7 and 8 show the calculated mean $\mathrm{pH}$ values and $\mathrm{pH}$ contours of Cogbill and Likens (1974) for 1955-56 and 1965-66, respectively, as well as confidence limits calculated from the error analysis for the charge balance and source strength methods. For the fairly acidic precipitation sites $(\mathrm{pH}<4.6)$, the uncertainty is $\pm 0.1 \mathrm{pH}$ units. The uncertainty is much higher for the less acidic precipitation sites, especially those of relatively high ionic strength. If the uncertainty in the individual ion concentrations, is greater than $10 \%$, then the $\mathrm{pH}$ ranges given are of lower confidence than the $68.3 \%$ level.

The random errors are important in deciding where the $\mathrm{pH}$ contours should be placed. Cogbill and Likens (1974) also employed measured $\mathrm{pH}$ values and acidities from the work of Gambell and Fisher (1966) and Pearson and Fisher (1971), which have not been shown in Fig. 8. These direct 


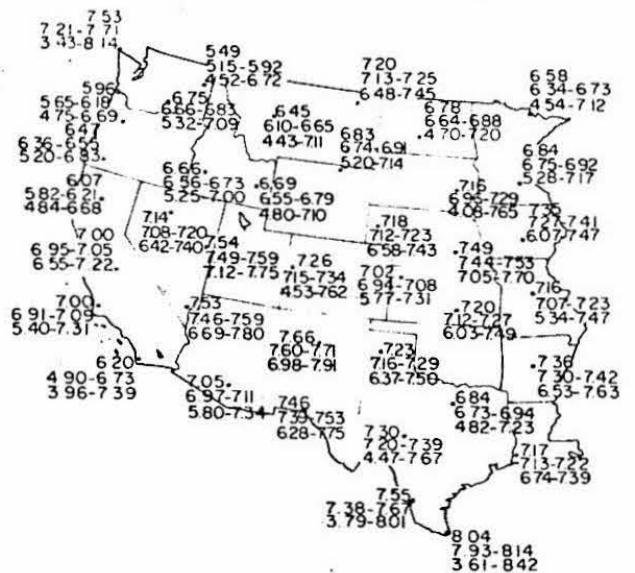

Fig. 9. Calculated mean $\mathrm{pH}$ values for the western United States during 1955-56. For each site, the top value is calculated by the charge balance from the data of Junge (1958) and Junge and Werby (1958). The middle row is the $68.3 \%$ confidence limits for the mean $\mathrm{pH}$ assuming a $10 \%$ coefficient of variation in the known mean major ion concentrations; the bottom row, the $95 \%$ confidence level assuming a $30 \%$ coefficient of variation.

measurements determine the location of portions of the $\mathrm{pH}$ contours in New England, Virginia, and North Carolina in Fig. 8. The isolines of low acidity (pH 5 and 5.6) are known with much less confidence than the contours of higher acidity. The overall conclusion that the acidity of precipitation in the eastern United States has increased in intensity is still evident even after applying error analysis. The increases in acidity of precipitation noted by Likens (1976) for the southcentral-southeastern United States are hard to quantify. The differences between the measured $\mathrm{pH}$ values of 1972-73 and the calculated values of 1955-56 and 1965-66 may be small because of the uncertainty in the calculated values around $\mathrm{pH}$ 5.6.

\subsection{Western United States}

Figures 9 and 10 show calculated mean $\mathrm{pH}$ values for the western United States for 1955-56 and 1960-66, respectively. The alkalinity of the rainwater is determined by the charge balance method with the data of Junge (1958), Junge and Werby (1958), and Lodge et al. (1968). Appropriate calcium-to-magnesium and ammonium-tonitrate ratios as described by Cogbill and Likens (1974) were used. For each site, the top value is the

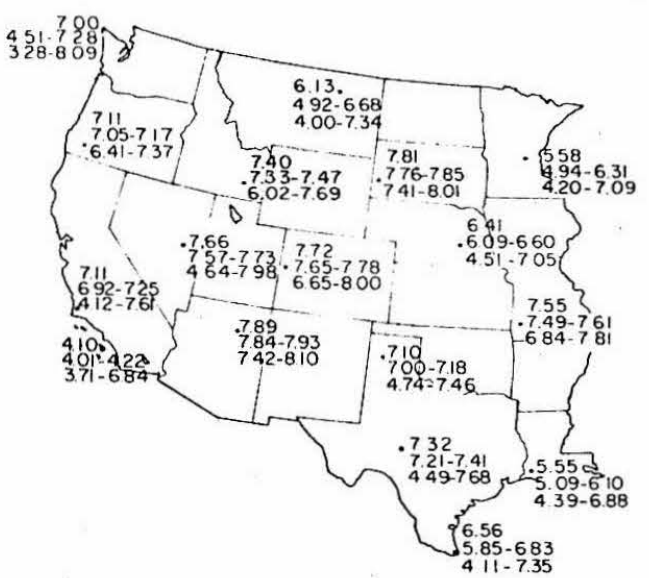

Fig. 10. Calculated mean $\mathrm{pH}$ values for the western United States during 1960-66. For each site, the top value is calculated by the charge balance from the data of Lodge et al. (1968). The middle row is the $68.3 \%$ confidence limits for the mean $\mathrm{pH}$ assuming a $10 \%$ coefficient of variation in the known mean major ion concentrations; the bottom row, the $95 \%$ confidence level assuming a $30 \%$ coefficient of variation.

calculated precipitation weighted mean, the second line gives the $68.3 \%$ confidence limits assuming a $10 \%$ coefficient of variation for each major ion concentration, and the bottom line gives the $95 \%$ confidence limits assuming a $30 \%$ coefficient of variation for the known ion concentrations. Thus, the bottom lines represent worst case analysis and the middle lines, best cases analysis for the ranges of mean pH values during the 1950's and 1960's.

Several implicit assumptions are made to arrive at the basic $\mathrm{pH}$ values for the West. First, the known cation and anion data represent the rainwater composition and are unchanged through biological action. The studies in the 1950's and 1960's used toluene as a preservative and biocide. Galloway and Likens (1978) noted a large variability in the potassium analyses when toluene was used to preserve precipitation samples, but other major ion concentrations were unaffected. Second, the precipitation samplings in the 1950's and 1960's were not biased by the samplers used. Since the samplers employed by Junge and Gustafson (1956) and Lodge et al. (1968) differed in their design and especially in being manually and automatically opened, respectively, some of the differences in the results for the 1950's and 1960's may be attributed to changes in sampling methods. Third, these 
theoretical $\mathrm{pH}$ values are based on the charge balance with no trace ions present. Granat (1972) empirically found acidity/alkalinity in precipitation samples to give $\mathrm{pH}$ values $0.1-0.15 \mathrm{pH}$ units lower for samples of $\mathrm{pH}<6.2$, and $0.67 \mathrm{pH}$ units lower for samples of $\mathrm{pH}>6.2$ than the $\mathrm{pH}$ values obtained from the theoretical relationship given in eq. (11). No empirical corrections have been made.

Figs. 9 and 10 imply that the western United States probably had alkaline rain in the 1950's and 1960 's with perhaps some local areas of acidic precipitation. The alkalinity of soil dust has a larger effect in the West then the East and the acidity due to sulfuric and nitric acids is significantly less in the West. The limitations of the charge balance method do not exclude the possibility that some areas of the West may have been affected by acid precipitation before the 1970's. Overall, Fig. 10 for the $\mathrm{pH}$ of rain from 1960-66 agrees well with the values measured during June 1966 by the NCAR study (Likens, 1976). Fig. 9 agrees well with the median and mean bicarbonate concentrations reported for snow in the northern Sierra Nevada, Arizona, Utah, and Colorado. The recorded $\mathrm{pH}$ measurements of the snow were lower than those predicted from the bicarbonate determinations and agree well with those shown in Fig. 9 for northern California and southern Oregon (Feth et al., 1964). Whitehead and Feth (1964) reported median $\mathrm{pH}$ values of 5.95 and 5.6 during 1957-58 and 195859, respectively, for Menlo Park, California. The acidity of rainfall in southern California has also been implied by a few $\mathrm{pH}$ measurements (Carroll, 1962). Other areas of locally acid precipitation before the 1970's may not have been sampled.

Due to the limitations of the indirect quantifications of acidity/alkalinity, trends in $\mathrm{pH}$ changes in the western United States to the present are hard to determine. The NOAA-EPA study for 1972-73 shows less alkalinity in the rainwater in the West than implied by Figures 9 and 10 (Miller, 1977). Direct measurements of acidity/alkalinity are needed on a larger scale as proposed by Galloway and Cowling (1978) to obtain a more precise understanding of rainwater quality in the West and provide a baseline for future studies.

\section{Conclusions}

Indirect methods of calculating rainwater acidity have some fundamental limitations. Random uncertainty in the major ion concentrations can be important for rainwaters of relatively high ionic strength of any $\mathrm{pH}$, and especially for those around pH 5.65 for the charge balance and source strength methods and around $\mathrm{pH} 6.1$ for the conductivity balance. The exclusion of trace ions has a larger effect on the conductivity balance than on the other two indirect methods, but the conductivity balance may be useful in confirming calculated acid $\mathrm{pH}$ values where only total nitrogen data are available. The uncertainty arising from applying the indirect methods to historical data is high enough that the date of transition from alkaline to acid precipitation is hard to determine. Direct measurements of $\mathrm{pH}$, acidity and alkalinity as well as ionic composition are needed on a large scale throughout the United States to provide baseline values in many areas, to confirm trends in precipitation acidity and to avert ecological damage.

\section{Acknowledgements}

Study partially supported by a Du Pont Environmental Grant, Ford/Exxon Research Program, and an institutional grant from the Department of Energy.

\section{REFERENCES}

Bischof, W. and Bolin, B. 1966. Space and time variations of the $\mathrm{CO}_{2}$ content of the troposphere and lower stratosphere. Tellus 18, 155-159.

Carroll, D. 1962. Rainwater as a chemical agent of geologic processes-a review, U.S. Geol. Surv. Water Supply Pap. 1535-g, 1-18.

Cogbill, C. V. and Likens, G. E. 1974. Acid precipitation in the Northeastern United States. Water Resour. Res. $10,1133-1137$.
Dickson, W. 1975. The acidification of Swedish Lakes, Report Institute of Freshwater Research, Drottningholm, Sweden 54, 8-20.

Ekdahl, C. A. Jr. and Keeling, C. D. 1973. Quantitative deductions from the records at Mauna Loa Observatory and at the South Pole. In Carbon and the biosphere (ed. G. M. Woodwell and E. V. Pecan). AEC Conf-720510, 51-58.

Feth, J. H., Rogers, S. M. and Roberson, C. E. 1964. 
Chemical composition of snow in the Northern Sierra Nevada and other areas. U.S. Geol. Surv. Water Supply Pap. 1535-J, 1-39.

Galloway, J. N. and Cowling, E. B. 1978. The effects of precipitation on aquatic and terrestrial ecosystems: a proposed precipitation chemistry net-work. J. Air Pol. Con. Ass. 28, 229-235.

Galloway, J. N., Likens, G. E. and Edgerton, E. S. 1976. Hydrogen ion speciation in the acid precipitation of the northeastern United States. Water Air and Soil Pol. 6, 423-433.

Galloway, J. N. and Likens, G. E. 1978. The collection of precipitation for chemical analysis. Tellus 30, 71-82.

Gambell, A. W. and Fisher, D. W. 1966. Chemical composition of rainfall in eastern North Carolina and southeastern Virginia. U.S. Geol. Surv. Water Supply Pap. 1535-K, 1-41.

Granat, L. 1972. On the relation between $\mathrm{pH}$ and the chemical composition in atmospheric precipitation. Tellus, 24, 550-560.

Granat, L. 1977. On the variability of rainwater composition and errors in estimates of arial wet deposition. In Precipitation Scavenging (1974), ERDA CONF-741003, 531-548.

Junge, C. E. 1958. The distribution of ammonia and nitrate in rain water over the United States. Eos Trans. AGU 39, 241-248.

Junge, C. E. and Gustafson, P. E. 1956. Precipitation sampling for chemical analysis. Bul. Am. Meteorol. Soc. $37,344$.

Junge, C. E. and Werby, R. T. 1958. The concentration of chloride, sodium, potassium, calcium, and sulfate in rainwater over the United States, J. Meteorol. 15, 417-425.

Kennedy, V. C., Zellweger, G. W. and Auznzino, R. J. 1976. Composition of selected rain samples collected at Menlo Part, California in 1971. U.S.G.S. open file report 76-852, Menlo Park, Ca., 1-7.

Larson, T. E. and Hettick, I. 1956. Mineral composition of rainwater. Tellus 8, 191-201.

Lazrus, A. L., Lorange, E. and Lodge, J. P. Jr. 1970. Lead and other metal ions in United States precipitation. Env. Sci. Tech. 4, 55-58.

Likens, G. E. 1976. Acid precipitation. Chem. Eng. News. 54, 29-44.

\section{АНАЛИЗ ОШИБОК КОСВЕННЫХ МЕТОДОВ}

Прямыми измерениями рН и титрованием кислотности прослеживался за исторические времена рост кислотности осадков в Северной Европе. Для подтверждения измеренных кислотностей использовались косвенные методы, такие, как измерения проводимости и баланса заряда, а также модели химических источников. В отсутствие исторических результатов прямых измерений кислотности в осадках в Соединенных Штатах к обработке имеюшихся данные о составе дождевой воды применялись косвенные методы с целью получения количественных данных о кислотности. К сожалению, косвенные методы чувствительных к
Liljestrand, H. M. and Morgan, J. J. 1978. Chemical composition of acid precipitation in Pasadena. California, Env. Sci. Tech. 12, 1271-1273.

Miller, J. M., Lodge, J. P., Jr., Pate, J. B., Basbergill, W., Swanson, B. S., Hill, K. C., Lorange, E. and Lazrus, A. L. 1968. Chemistry of United States precipitation, 66 pp. National Center for Atmospheric Research, Boulder, Colo.

MAP3S Precipitation Chemistry Network: 1977. First periodic summary report (September 1976-June 1977), 173 pp. Pacific Northwest Laboratories, Richmond, Washington, ANL-2402, UC-11.

Miller, J. M. 1977. A statistical evaluation of the U.S. precipitation chemistry network, in Precipitation Scavenging (1974). ERDA CONF-741003, 639-659.

Miller, J. P. 1952. A portion of the system calcium carbonate-carbon dioxide-water with geological implications. Am. Jour. Sci. 250, 161-203.

Odẻn, S. 1968. Nederbördens och luftens försurning-dess orsaker, förlopp och verkan i olika miljöer, Statens Naturvetenskapliga Forskningsräd, Ekologikommittéen. Stockholm, Bulletin No. 1.

Pearson, F. J. Jr., and Fisher, D. W. 1971. Chemical composition of atmospheric precipitation in the northeastern United States. U.S. Geol. Surv. Water Supply Pap. 1535-P, 1-23.

Stumm, W. and Morgan, J. J. 1970. Aquatic Chemistry. Wiley-Interscience, New York.

Whitehead, H. C. and Feth, J. H. 1964. Chemical composition of rain, dry fallout, and bulk precipitation at Menlo Park, California, 1957-1959. J. Geophys. Res. 69, 3319-3333.

WMO, EPA and NOAA, 1975. Atmospheric Turbidity and Precipitation Chemistry Data for the World 1973. Environmental Data Service, National Climatic Center, Asheville, North Carolina.

WMO, EPA and NOAA, 1976. Atmospheric Turbidity and Precipitation Chemistry Data for the World 1974. Environmental Data Service, National Climatic Center, Asheville, North Carolina.

WMO, EPA and NOAA, 1977. Global Monitoring of the Environment for Selected Atmospheric Constituents 1975. Environmental Data Service, National Climatic Center, Asheville, North Carolina.

\section{ОПРЕДЕЛЕНИЯ КИСЛОТНОСТИ ОСАДКОВ}

малым ошибкам в определенных интервалах значений $\mathrm{pH}$. Показано, что влияние случайных ошибок из-за исключения следов металлических и органических ионов наиболее сильно вблизи $\mathrm{pH}=$ 5,6 при рассмотрении баланса заряда и при вычислении мощности химического источника и вблизи $\mathrm{pH}=6,1$ в методе баланса проводимости. Оценки нсопределснности в исторических значениях конщентрации ионов в осадках используются для вычисления верхней и нижнсй границ кислотности дождевой воды в США для времен до 1970 r. 